\title{
KEDUDUKAN PERATURAN DESA DALAM HIERARKI PERUNDANG- UNDANGAN SETELAH KELUARNYA UNDANG-UNDANG NOMOR 12 TAHUN 2011
}

\author{
Imelda Sapitri \\ Imelda932016@gmail.com Universitas Islam Riau \\ Deni Jaya Saputra \\ Denijayas0880@gmail.com Universitas Islam Riau
}

\begin{abstract}
This article is about position of village regulation in hierarchy of legislation laws after coming the law number 12 of 2011 about village regulation based on law number 10 of 2004 stated that one of the regulation in law hierarchy as long as in section 7 verse (2). Moreover, after coming the law number 12 of 2011 that changed the law number 10 of 2004 village regulation is not appear in hierarchy but still effect as in section 101 said that: "all of laws is the implication of law number 10 of 2004, it was stated that effect as long as incompatible with this law regulation". Village regulation is also get attribution of authority law number 6 of 2014 about village. Therefore, it is clear that status of village regulation is law legislation which have the power of laws. In this autonomy, the village is given the authority to organize and manage its own so that the village regulation become important to implement the authority that to be more effective.
\end{abstract}

Keywords: Village Regulation, Village Representative Board, and Hierarchy.

\begin{abstract}
Abstrak
Artikel ini membahas kedudukan peraturan desa dalam hierarki peraturan perundang-undangan setelah keluarnya Undang-undang Nomor 12 Tahun 2011. Peraturan desa berdasarkan undang-undang nomor 10 tahun 2004 merupakan salah satu peraturan yang masuk dalam hierarki perundangan-undangan sebagaimana diatur dalam pasal 7 ayat (2). Namun setelah keluarnya undang-undang nomor 12 tahun 2011 menggantikan undang-undang nomor 10 tahun 2004 peraturan desa tidak lagi terlihat di dalam hierarki, meskipun tidak terlihat dalam hierarki
\end{abstract}


peraturan desa masih tetap berlaku sesuai dengan bunyi pasal Pasal 101 berbunyi: "semua Peraturan Perundang-undangan yang merupakan peraturan pelaksanaan dari Undang-Undang Nomor 10 Tahun 2004, dinyatakan masih tetap berlaku sepanjang tidak bertentangan dengan ketentuan dalam Undang-Undang ini”. Peraturan desa juga mendapatkan atribusi kewenangan dari undang-undang nomor 6 tahun 2014 tentang desa. Dengan demikian jelaslah bahwa status peraturan desa merupakan peraturan perundang-undangan yang memiliki kekuatan hukum. Dalam era otonomi ini desa diberikan kewenangan untuk mengatur dan mengurus rumah tangganya sendiri sehingga peraturan desa menjadi penting untuk mengimplementasikan kewenangan yang dimilikinya agar lebih efektif.

\section{Kata Kunci : Peraturan Desa, Badan Permusyawaratan Desa, Hierarki}

\section{Pendahuluan}

Negara Indonesia adalah Negara Kesatuan yang Berbentuk Republik dalam penjelasannya diterangkan bahwa melindungi segenap Bangsa Indonesia dan seluruh tumpah darah Indonesia dengan berdasarkan persatuan dengan mewujudkan keadilan sosial bagi seluruh Rakyat Indonesia. ${ }^{1}$ Kedaulatan yang sesungguhnya berasal dari rakyat, oleh rakyat, dan untuk rakyat (demokrasi). Pelaksanaan kedaulatan rakyat tersebut disalurkan dan diselenggarakan menurut prosedur konstitusional, yang diatur didalam UndangUndang Dasar 1945, sebagai peraturan dasar atau konstitusi yang merumuskan dan mengatur sistem ketatanegaraan dan tata cara pelaksanaan pemerintahan di Negara Kesatuan Republik Indonesia. Undang-Undang Dasar 1945 sebagai peraturan dasar atau konstitusi Republik Indonesia, telah mengalami empat kali perubahan atau amandemen.

${ }^{1}$ Josef Riwu Kaho, Prospek Otonomi Daerah di Negara Republik Indonesia, PT Raja Grafindo Persada, Jakarta, 2002. hlm 3. 
Dalam Undang-undang Dasar 1945 Pasal 18 ayat 6 berbunyi "Pemerintahan Daerah berhak menetapkan peraturan daerah dan peraturan-peraturan lain untuk melaksanakan otonomi dan tugas pembantuan". Indonesia yang menganut sistem Otonomi Daerah, yang memiliki cakupan penyelenggaraan pemerintah yang luas wilayahnya dan keberadaan pemerintahan daerah tersebut sangatlah dibutuhkan peraturan perundang-undangan yang bersifat dan berlaku khusus untuk suatu daerah. Perundang-undangan yang bersifat dan berlaku khusus untuk suatu daerah, sangatlah penting dikarenakan Indonesia memiliki heterogenitas baik kondisi sosial, ekonomi, budaya maupun keragaman tingkat Pendidikan masyarakat, maka desenralisasi kekuasaan /kewenangan dari pemerintah pusat perlu dialirkan kepada daerah yang berotonom. $^{2}$

Dalam undang-undang Nomor 12 tahun 2011 tentang pembentukan peraturan perundang-undangan peraturan desa tidak lagi disebutkan secara eksplisit sebagai salah satu jenis peraturan perundangundangan yang diatur dalam pasal 7 ayat (1). Berbeda dengan Undangundang Nomor 10 Tahun 2004 tentang pembentukan peraturan perundang-undangan Pasal 7 ayat (2) menyatakan Peraturan Daerah meliputi:

a) Peraturan Daerah provinsi dibuat oleh dewan perwakilan rakyat daerah provinsi bersama dengan gubernur.

b) Peraturan Daerah kabupaten/kota dibuat oleh dewan perwakilan rakyat daerah kabupaten/kota bersama bupati/walikota.

c) Peraturan Desa/peraturan yang setingkat, dibuat oleh badan perwakilan desa atau nama lainnya bersama dengan kepala desa atau nama lainnya.

Dengan tidak disebutkannya Peraturan Desa seperti yang diatur dalam undang-undang nomor 10 tahun 2004 hal ini menimbulkan suatu

${ }^{2}$ J. Kaloh, Mencari Bentuk Daerah, Rineka Cipta, Jakarta, 2007. hlm 1 
kerancuan dan perdebatan mengenai kedudukan peraturan desa setelah berlakunya Undang-undang Nomor 12 Tahun 2011.

\section{Kajian Pustaka}

Para ahli sejarah memandang desa sebagai sumber kekuatan dan ketahanan dasar dalam mempertahankan kemerdekaan (community power). Bahkan menurut Ndraha, desa dianggap sebagai sumber nilai luhur yang memiliki karakteristik seperti kegotongroyongan, musyawarah, mufakat, dan kekeluargaan, sehingga menimbulkan berbagai semboyan. Menurut Mutty, desa sebagai suatu lembaga pemerintahan dengan hak otonomi yang dimilikinya telah mendapat pengakuan jauh sebelum dilaksanakannya pemerintahan dengan asas desentralisasi. Perkataan Desa, Dusun, Desi, Negara, Negeri, Negari, Nagaro, Negory asalnya adalah dari bahasa sansekerta yang artinya tanah air, tanah asal atau tanah kelahiran. Perkataan desa hanya dipakai di kalangan orang Jawa, sedangkan di kalangan orang Madura dan Bali menggunakan istilah dusun dan marga, dusundati (Maluku). Kuta/huta (Batak), Nagari (Minangkabau), dan Gampong/Meunasah (Aceh). Dalam Undang-Undang Nomor 23 Tahun 2014 tentang Pemerintahan Daerah selanjutnya secara seragam disebut Desa. Dengan demikian negara tetap mengakui dan menghormati kesatuan-kesatuan masyarakat hukum adat, beserta hak tradisionalnya sepanjang masih hidup dan sesuai dengan perkembangan masyarakat dan prinsip negara Kesatuan Republik Indonesia. Sebagaimana tertuang dalam Pasal 1 Angka 4 yang berbunyi : Desa adalah desa dan desa adat atau yang disebut dengan nama lain, selanjutnya disebut Desa, adalah kesatuan masyarakat hukum yang memiliki batas wilayah yang berwenang untuk mengatur dan mengurus Urusan Pemerintahan, kepentingan masyarakat setempat berdasarkan prakarsa masyarakat, hak asal usul, dan/atau hak tradisional yang diakui dan dihormati dalam sistem pemerintahan Negara Kesatuan Republik Indonesia. 
Pra kemerdekaan, Indonesia dijajah Belanda dan Jepang. Penjajah telah menerapkan desentralisasi yang bersifat sentralistik, birokratis, dan feodalistik untuk kepentingan mereka. Belanda menyusun suatu hierarki Pangreh Praja Bumiputra dan Pangreh Praja Eropa yang harus tunduk kepada Gubernur Jenderal. Dikeluarkannya Decentralistie Wet pada tahun 1903, yang ditindaklanjuti dengan Bestuurshervorming Wet pada tahun 1922, menetapkan daerah mengatur rumah tangganya sendiri sekaligus membagi daerah-daerah otonom yang dikuasai belanda menjadi gewest (identik dengan provinsi saat ini), regentschap (kabupaten saat ini) dan staatgemeente (kotamadya sekarang). ${ }^{3}$ Pada masa pemerintahan kolonial Belanda, peraturan tentang konsep kesatuan masyarakat kecil masih ada dan dilindungi, namun pemerintah kolonial tidak secara implisit menyebutkan bahwa kesatuan masyarakat kecil tersebut adalah desa. Istilah yang dipakai untuk desa adalah Inlandspe Gemeente. Istilah ini terlihat pada RR (Regeringsreglement) dan pada IS (Indische Staatsregeling) ataupun tercantum dalam IGO (Inlandse Gemeente Ordonnantie) dan IGOB (Inlandse Gemeente Ordonnantie Buitenwegesten) dan banyak peraturan lainnya pada masa lalu yang tidak dengan jelas memberikan rumusan tentang apa yang disebut dengan desa. $^{4}$

Pembentukan norma hukum pada hakikatnya adalah pembentukan peraturan perundang-undangan. Peraturan perundang-undangan adalah keputusan tertulis negara atau pemerintah yang berisi petunjuk atau pola tingkah laku yang bersifat dan mengikat secara umum. ${ }^{5}$ Sedangkan undang-undang yang dikenal dalam literatur adalah "local statute" atau "local wet" yaitu undang-undang yang bersifat lokal. Dalam pasal 18 ayat (6) UUD 1945 menentukan bahwa " Pemerintah Daerah berhak

${ }^{3}$ Mudrajat Kuncoro, Otonomi Daerah Menuju Era Baru Pembangunan Daerah, Edisi 3, Erlangga, Jakarta, 2014. hlm 5

${ }^{4}$ Ibid

${ }^{5}$ Yuliandri, Asas-Asas Pembentukan Peraturan Perundang-undangan yang baik, Rajawali Pers, Jakarta, 2010. hlm 25 
menetapkan peraturan daerah dan peraturan-peraturan lain untuk melaksanakan otonomi dan tugas pembantuan". Dengan kata lain, pemerintah daerah berhak menginstruksikan pembentukan peraturan desa yang dibentuk atas kerjasama Kepala Desa dan Badan Permusyawaratan Desa.

Peraturan desa merupakan bagian dari peraturan daerah yang dibuat oleh Badan Permusyawaratan Desa bersama kepala desa dimana tata cara pembentukannya diatur oleh Peraturan Daerah Kabupaten/Kota yang bersangkutan. Peraturan Desa biasanya bersifat lokal dan biasanya berhubugan dengan adat istiadat desa/masyarakat dan mengikat masyarakat setempat atau warga desa lain yang tinggal sementara di desa tersebut ${ }^{6}$. Peraturan desa merupakan regulasi yang sangat penting, apalagi di Indonesia. Hal tersebut dikarenakan Indonesia merupakan Negara yang multi, yang menimbulkan keberagaman sumber daya alam, sumber daya manusia, kebutuhan masyarakat yang berbeda-beda, luas wilayah, adat istiadat, Agama dan budaya. Yang tidak cukup hanya di atur oleh undang-undang dan peraturan daerah, yang materi muatannya memiliki cakupan yang lebih luas.

Pentingnya peraturan desa, secara normatif untuk melaksanakan perintah peraturan perundang-undangan yang lebih tinggi sebagaimana pembentukan peraturan desa mendapat atribusi kewenangan dari undang-undang nomor 6 tahun 2014 tentang desa. Desa dalam era otonomi daerah diberikan kewenangan untuk mengatur dan mengurus rumah tangganya sendiri perlu peraturan desa untuk mengimplementasikan kewenangannya sehingga menjadi lebih efektif. Dengan adanya peraturan desa kehidupan demokrasi di desa tidak hanya terlihat ketika pemilihan kepala desa tetapi juga dalam proses pembentukan peraturan desa yang mengedepankan musyawarah dan masyarakat ikut berpartisipasi secara aktif dengan cara menyampaikan

\footnotetext{
${ }^{6}$ http://carapedia.com/peraturan_desa_info661.html
} 
gagasan-gagasannya yang akan dituangkan dalam peraturan desa sehingga hak-hak masyarakat tidak dilanggar.

Selain itu, dengan adanya peraturan desa sebagai pengetahuan bagi masyarakat terkait fungsi pemerintahan desa. Dengan adanya peraturan desa mempercepat sejeahteraan masyarakat melalui peningkatan, pelayanan, pemberdayaan, dan peran serta masyarakat, serta peningkatan daya saing daerah dengan memperhatikan prinsip demokrasi, pemerataan, keadilan, keistimewaan dan kekhususan suatu daerah dalam sistem Negara Kesatuan Republik Indonesia. Akan tetapi, peraturan desa yang dibuat hendaknya mempertimbangkan keutuhan dan kemampuan masyarakat untuk melaksanakannya. Untuk itu, maka proses penyusunan peraturan desa harus memperhatikan asprirasi masyarakat. Sebagai pedoman dalam penyelenggaraan desa, peraturan desa juga memenuhi asas sebagai berikut: ${ }^{7}$

a) Asas kepastian hukum yaitu asas dalam negara hukum yang mengutamakan landasan peraturan perundang-undangan, kepatutan dan keadilan dalam setiap kebijakan penyelenggaraan negara.

b) Asas tertib penyelenggaraan negara yaitu asas yang menjadi landasan keteraturan, keserasian, dan keseimbangan dalam pengendalian penyelenggaraan negara.

c) Asas keterbukaan yaitu asas yang membuka diri terhadap hak masyarakat untuk memperoleh informasi yang benar, jujur dan tidak diskriminatif tentang penyelenggaraan negara dengan tetap memperhatikan perlindungan atas hak asasi pribadi, golongan dan rahasian negara.

Reformasi adalah suatu usaha yang dimaksud agar praktik-parktik politik, pemerintah, ekonomi dan sosial budaya yang dianggap oleh masyarakat tidak sesuai dan tidak selaras dengan kepentingan

${ }^{7}$ Siswanto Sunarno, Hukum Pemerintahan Daerah di Indonesia, Sinar Grafika, Jakarta, 2006.hlm. 34 
masyarakat dan aspirasi masyarakat diubah atau ditata ulang agar menjadi lebih sesuai dan lebih selaras (sosio-reformasi). Dengan demikian maka kepentingan dan aspirasi masyarakat menjadi landasan dan sekaligus tujuan reformasi. Landasan tersebut menjadikan tolok ukur, kriteria, dan batu uji dari reformasi itu sendiri. Perbedaan pendapat dalam demokrasi adalah wajar, bila terdapat perbedaan anatar kepentingan pemerintah dan masyarakat, maka kepentingan masyarakatlah yang didahulukan atau diutamakan. Dengan perkataan lain, reformasi adalah suatu usaha atau upaya untuk menghidupkan demokrasi terutama di bidang politik, pemerintahan, ekonomi dan sosial budaya. ${ }^{8}$ Sebagai sebuah produk politik, peraturan desa juga proses secara demokratis dan partisipatif, yakni suatu proses penyusunan yang mengikutsertakan partisipasi masyarakat desa setempat. Masyarakat desa juga mempunyai hak untuk mengusulkan atau memberikan masukan kepada Kepala Desa dan Badan Permusyawaratan Desa (BPD) dalam proses penyusunan peraturan desa. $^{9}$

Pentingnya partisipasi masyarakat dalam menentukan keberhasilan penyelenggaraan pemerintahan desa dapat dijelaskan seperti uraian sebagai berikut:

1. Partisipasi masyarakat merupakan pemenuhan terhadap etika politik yang menempatkan rakyat sebagai sumber kekuasaan dan kedaulatan; ${ }^{10}$

2. Partisipasi masyarakat didasarkan pada pertimbangan bahwa kedaulatan ada ditangan rakyat yang melaksanakannya melalui kegiatan bersama untuk menetapkan tujuan serta masa depan masyarakat itu dan untuk menentukan orang-orang yang akan memegang tampuk pimpinan untuk masa berikutnya;

8 Haw Widjaja, Otonomi Daerah Dan Daerah Otonom, PT Raja Grafindo Persada, Jakarta, 2016. hlm 74

9 Rahyunir Rauf, Sri Maulidiah, Badan Permusyawaratan Desa, Zanafa, Pekanbaru, 2016. hlm 290 Op.Cit, hlm 110

${ }_{10}$ Josef Riwu Kaho, Prospek Otonomi Daerah Di Negara Republik Indonesia,.. 
3. Partisipasi terkait langsung dengan ide demokrasi, dimana prinsip dasar demokrasi dari rakyat, oleh rakyat dan untuk rakyat, akan memberikan pada setiap warga negara kemungkinan untuk menaiki jenjang atas skala sosial dan dengan demikian menurut hukum membuka jalan bagi hak-hak masyarakat terpenuhi dalam produk politik;

4. Partisipasi masyarakat dalam proses pembuatan keputusan Moebyarto menegaskan dalam keadaan yang paling ideal keikutsertaan masyarakat untuk membuat putusan politik yang menyangkut nasib mereka, adalah ukuran tingkat partisipasi rakyat. Semakin besar kemampuan untuk menentukan nasib sendiri, semakin besar partisipasi masyarakat dalam pembangunan.

5. Hukum bukanlah sebuah mekanisme yang dibuat dan bekerja di dalam sebuah ruang hampa. Hukum senantiasa berinteraksi dengan berbagai faktor-faktor yang bersifat non hukum (faktor sosial). Secara teoritis di dalam ilmu hukum dikenal adanya fiksi hukum yang menyatakan bahwa semua orang dianggap tahu hukum, namun teori fiksi ini tidak dapat diberlakukan begitu saja, masalah komunikasi sering kali muncul karena selama ini pemerintah kurang dalam mengumumkan peraturannya (sosialisasi). Partisipasi masyarakat dalam penegakan suatu peraturan perundang-undangan adalah salah satu bentuk dimana hukum dipengaruhi oleh faktor sosial yang ada disekitarnya. Kesenjangan antara das sollen dengan das sein adalah suatu hal yang lazim ditemui di dunia hukum. Demikian halnya dengan proses penegakan hukum yang tidak dapat berjalan sebagaimana yang direncanakan sebelumnya. Pada proses penegakan ini masyarakat berada pada posisi sentral. Peran serta masyarakat dalam penegakan peraturan perundang-undangan dilakukan dengan cara : Mentaati peraturan yang sudah ada, mencegah 
pelanggaran yang diketahui akan dilakukan orang lain, mengkritik penegakan peraturan yang dilakukan dengan setengah hati.

Lawrence Meir Friedman mengatakan bahwa sistem hukum terdiri dari tiga komponen yang meliputi legal structure (Struktur Hukum), legal substance (substansi hukum) dan legal culture (budaya hukum). Pembagian sistem hukum kedalam tiga komponen sebagaimana dimaksud, bertujuan untuk menganalisa bekerjanya suatu sistem hukum atau hukum yang sedang beroperasi dalam studi tentang hukum dan masyarakat. Teori Lawrence di kaitkan dengan peraturan desa dari segi struktur hukum yaitu Badan Permusyawaratan Desa dan Kepala desa yang berwenang membuat peraturan desa. Sebelum peraturan desa ditetapkan hendaklah melakukan musyawarah dengan masyarakat setempat untuk menghindari peraturan desa bertentangan dengan adat istiadat serta melanggar hak-hak masyarakat. Dari segi substansi hukum, isi dari peraturan desa tersebut tidak boleh bertentangan dengan peraturan perundang-undangan yang lebih tinggi, kepentingan umum serta adat istiadat yang berlaku di desa tersebut. Dari segi budaya hukum, masyarakat harus andil dalam melakukan penegakan terhadap peraturan desa dengan cara seperti yang sudah disebutkan diatas yaitu: mentaati peraturan yang sudah ada, mencegah pelanggaran yang diketahui akan dilakukan orang lain, mengkritik penegakan peraturan yang dilakukan dengan setengah hati

Beberapa contoh peraturan desa yang biasa ditemui di beberapa desa di Indonesia yaitu seperti: ${ }^{11}$

a. Pelaksanaan acara bersih desa;

b. Peraturan tentang tata cara merawat area makam leluhur desa setempat;

C. Proses pemilihan kepala desa dan perangkat desa;

d. Peraturan tentang pembagian air;

e. Pemanfaatan tanah bagi kepala desa;

${ }^{11}$ www.hukumonline.com 
f.Pembentukan lembaga kemasyarakatan;

g. Pengelolaan keuangan desa yang disusun dalam APBD (anggaran pendapatan belanja desa).

\section{Metode Penelitian}

1. Jenis dan Sifat Penelitian

Jenis penelitian ini termasuk dalam golongan penelitian hukum normatif adalah penelitian kepustakaan, yaitu penelitian terhadap data sekunder. ${ }^{12}$ Sedangkan dilihat dari sifatnya adalah deskriptif analitis yaitu analisis yang dilakukan untuk menilai karakteristik dari sebuah data.

2. Data dan Sumber Data

Dalam penelitian hukum normatif data dan sumber data yang digunakan adalah data sekunder yang dapat dikelompokkan menjadi:

a. Bahan hukum primer merupakan bahan yang menjadi sumber utama dalam penelitian. Bahan hukum primer dalam penelitian ini adalah : Undang-Undang Dasar Negara Republik Indonesia Tahun 1945, Undang-Unndang Nomor 12 Tahun 2011 Tentang Pembentukan Peraturan Perundang-Undangan, Undang-Undang Nomor 4 Tahun 2016 Tentang Desa dan Undang-Undang Nomor 23 Tahun 2014 Tentang Pemerintahan Daerah;

b. Bahan hukum sekunder yang terutama adalah buku-buku hukum termasuk skripsi, tesis dan disertasi. Disamping itu juga jurnal hukum atau majalah ilmiah yang diterbitkan oleh lembaga pendidikan. ${ }^{13}$

c. Bahan hukum tersier merupakan bahan-bahan yang mempunyai fungsi untuk memberikan penjelasan terhadap bahan hukum primer dan bahan hukum sekunder. Bahan hukum tersier antara lain kamus hukum/bahasa, ensiklopedi, dan lain-lain.

${ }^{12}$ Zainuddin Ali, Metode Penelitian Hukum, Sinar Grafika, Jakarta, 2014. HIm.

${ }^{13}$ Suratman, Metode Penelitian Hukum, Alfabeta, Bandung, 2014. HIm. 77 


\section{Anlisis Data dan Metode Penarikan Kesimpulan}

Peneliti bidang hukum dengan menggunakan metode penelitian hukum normatif, dan data dianalisis secara kualitatif. Analisis secara kualitatif merupkan analisis dengan mendeskripsikan/menggambarkan, kemudian membandingkan antara data dengan ketentuan-ketentuan peraturan perundang-undangan atau pendapat para ahli hukum. Penarikan kesimpulan dilakukan dengan cara deduktif penyimpulan dari hal-hal yang bersifat umum kepada hal-hal yang bersifat khusus.

\section{Hasil Penelitian dan pembahasan (Kedudukan peraturan desa dalam hierarki perundang-undangan setelah keluarnya undang- undang Nomor 12 tahun 2011).}

Kepala Desa dipilih oleh masyarakat desa melalui pemilihan umum kepala desa. Seorang kepala desa haruslah seorang Warga Negara Republik Indonesia yang memenuhi syarat yang selanjutnya akan ditentukan dalam perda tentang tata cara pemilihan kepala desa, calon yang memperoleh suara terbanyak ditetapkan menjadi kepala desa terpilih. Masa jabatan kepala desa adalah enam tahun dan dapat dipilih kembali hanya untuk satu kali masa jabatan berikutnya. Kepala desa terpilih dilantik oleh bupati /walikota paling lambat tiga puluh hari setalah calon tersebut dinyatakan sebagai calon terpilih. Kepala desa dalam hal ini pemerintah desa telah diberikan kewenangan untuk mengatur dan mengurus urusan pemerintah dan kepentingan masyarakat desa setempat, berdasarkan prakarsa masyarakat, hak asal usul, dan/atau hak tradisional, maka dengan ketentuan seperti tersebut. ${ }^{14}$

Maka berarti desa dapat mengatur dan membuat berbagai bentuk peraturan desa dan mengurus yang berarti pemerintahan desa dapat menjalankan fungsi-fungsi manajemen dan administrasi pemerintahan.

14 Rozali Abdullah, Pelaksanaan Otonomi Luas Dengan Pemilihan Kepala Daerah Secara Langsung, PT Raja Grafindo Persada, Jakarta, 2011. hlm171 
Dalam rangka melaksanakan kewenangan yang dimiliki untuk mengatur dan mengurus kepentingan masyarakatnya, di desa atau yang disebut nama lain dibentuk Badan Permusyaratan Desa sebagai lembaga legislasi (menetapkan peraturan desa) dan menampung serta menyalurkan aspirasi masyarakat bersama kepala desa.

Lembaga ini pada hakikatnya adalah mitra kerja pemerintah desa yang memiliki kedudukan sejajar dalam menyelenggarakan urusan pemerintahan, pembangunan dan pemberdayaan masyarakat. Sebagai lembaga legislasi, BPD memiliki hak menyetujui atau tidak terhadap peraturan desa yang dibuat oleh pemerintah desa. Lembaga ini juga dapat membuat rancangan peraturan desa untuk bersama-sama pemerintah desa ditetapkan menjadi peraturan desa. Disini, terjadi mekanisme checks and balance system ${ }^{15}$ dalam penyelenggaraan pemerintahan desa yang lebih demokratis. Dalam hal BPD sebagai lembaga pengawas, BPD memiliki kewajiban untuk mengontrol terhadap implementasi peraturan desa, Anggaran Pendapatan dan Belanja Desa (APBD) serta pelaksanaan keputusan kepala desa. Selain itu, di desa dapat dibentuk pula lembaga kemasyarakatan desa sesuai kebutuhan desa untuk meningkatkan partisipasi masyarakat dalam penyelenggaraan pembangunan. ${ }^{16}$

Badan Permusyawaratan Desa beranggotakan pemuka masyarakat di Desa dibentuk dengan maksud dan tujuan untuk memperkuat pemerintahan desa agar mampu menggerakkan untuk berpartisipasi aktif dalam berbagai kegiatan pembangunan desa serta sebagai perwujudan

15 Checks and balance adalah teori yang berkembang dalam sistem ketatanegaraan Amerika Serikat. Teori ini memodifikasi ajaran pemisahan kekuasaan (separation of power) Montesquieu yang begitu kaku. Seperti diketahui UUD Amerika Serikat berusaha menjelmakan sejauh mungkin ajaran pemisahan kekuasaan. Tetapi apabila ajaran pemisahan kekuasaan itu tanpa diimbangi oleh suatu Checks And Balance mungkin akan menimbulkan kesewenang-wenangan baru. Karena setiap cabang kekuasaan dapat bertindak atas kemauan sendiri tanpa ada badan lain yang berwenang mengeroksi tindakannya. Kalau sebelumnya, ada ajaran pemisahan kekuasaan kesewenang-wenangan timbul karena bersatunya cabang kekuasaan disatu tangan (absolute), sekarang justru karena pemisahan kekuasaan. Ellydar Chaidir, Sistem Pemerintahan Negara Republik Indonesia, Total Media, Yogyakarta, 2008. hlm 60

${ }^{16}$ Muhadam Labolo, Memahami IImu Pemerintahan, PT Raja Grafindo Persada, Jakarta, 2006. HIm. 148 
pelaksanaan demokrasi masyarakat ditingkat desa. Kondisi diatas menunjukkan bahwa pada saat di desa terdapat eksekutif desa dan legislatif desa, dimana kepala desa beserta perangkat desa menjalankan fungsi eksekutif desa, dan Badan Permusyawaratan Desa menjalankan fungsi legislatif. Kehadiran BPD mampu diharapkan mampu menghidupkan dan mengembangkan nilai-nilai demokrasi di desa serta mampu untuk menggerakkan masyarakat desa untuk terlibat aktif dalam pembangunan desa. Masa jabatan anggota BPD adalah enam tahun, sama dengan masa jabatan kepala desa, dan dapat dipilih kembali untuk satu kali masa jabatan berikutnya.

Secara normatif, mengenai kemandirian untuk mengatur itu diwujudkan melalui pembentukan produk hukum yang sifat umumnya seperti peraturan desa, sedangkan kemandiriannya untuk mengurus diwujudkan melalui pembentukan produk hukum penjabaran yang bersifat lebih kongkret, seperti peraturan Kepala Desa. Mengambil sebagian teks pembukaan UUD 1945, pada alinea ke 4 dinyatakan sebagai berikut: "Untuk membentuk suatu pemerintahan negara Indonesia yang melindungi segenap bangsa Indonesia dan seluruh tumpah darah Indonesia dan untuk memajukan kesejahteraan umum, mencerdaskan kehidupan bangsa, dan ikut melaksanakan ketertiban dunia yang berdasarkan kemerdekaan, perdamaian abadi dan keadilan sosial. Memerhatikan kandungan alinea ke-4, maka tugas yang diemban oleh negara dalam menyelenggarakan kesejahteraan umum tersebut, menjadi sangat penting kedudukan dan fungsi dari arti pembentukan peraturan perundang-undangan di Negara republik Indonesia. ${ }^{17}$

Peraturan perundang-undangan adalah semua hukum dalam arti luas yang dibentuk dengan cara tertentu, oleh pejabat yang berwenang dan dituangkan dalam bentuk tertulis. Hukum perundang-undangan yang menekankan pada bentuk tertulis ini semula terkait erat dengan sistem

${ }^{17}$ Azmi Fendri, Pengaturan Kewenangan Pemerintah Dan Pemerintah Daerah Dalam Pemanfaatan Sumber Daya Mineral Dan Batu Bara, PT Raja Grafindo Persada, Jakarta, 2016. hlm. 138 
hukum eropa kontinental yang menganut legisme dengan civil law. Namun sekarang ini, terutama dalam kaitannya dengan pengujian yudisial, adanya peraturan perundang-undangan dengan susunan hierarkisnya tidak hanya terkait dengan civil law di Eropa Kontinental, tetapi juga berlaku di negara-negara anglo saxon meskipun pada umumnya kawasan ini dikenal sebagai penganut common law. Perbedaan antara eropa kontinental (civil law) dan anglo saxon (common law) dewasa ini lebih tertuju pada tumpuan strategi pembangunan hukumnya, yang satu menekankan pada peran lembaga legislatif dan eksekutif untuk membuat hukum-hukum tertulis, sedangkan yang satunya lebih menekankan pada peran lembaga legislatif dan eksekutif untuk membuat hukum tertulis, sedangkan yang satunya lebih menekankan peran-peran lembaga yudisial untuk membuat hukum melalui vonis-vonisnya yang kreatif dengan menggali nilai-nilai keadilan di dalam masyarakat. ${ }^{18}$

Dengan demikian, jika kita memetakan berdasar sejarah dan kawasan maka ada dua tradisi dan sistem yang melahirkan konsepsi negara hukum, yaitu :

1. Tradisi Eropa Kontinental dengan civil law yang menekankan pada hukum tertulis agar terdapat kepastian hukum. Negara hukumnya disebut Rechtsstaat;

2. Tradisi Anglo Saxon dengan common law yang menekankan pada yurisprudensi guna mencapai penegakan rasa keadilan. Negara hukumnya disebut The Rule Of Law.

Hukum dalam arti luas mencakup semua peraturan yang dibuat oleh lembaga-lembaga tertentu sesuai dengan tingkat dan lingkup kewenangannya yang biasanya disebut peraturan perundang-undangan. Dengan demikian, peraturan perundang-undangan adalah berbagai jenis peraturan tertulis yang dibentuk oleh berbagai lembaga sesuai tingkat dan lingkupnya masing-masing. Semua peraturan yang mengikat itu disusun

${ }^{18}$ Mahfud MD, Konstitusi Dan Hukum Dalam Kontroversi Isu, Jakarta, PT Raja Grafindo Persada, 2009. hlm. 257 
secara hierarkis untuk menentukan derajatnya masing-masing dengan konsekuensi jika ada peraturan yang bertentangan maka yang dinyatakan berlaku adalah yang derajatnya lebih tinggi ${ }^{19}$. Studi hukum hampir selalu mengaitkan masalah susunan hierarkis ini dengan teori penjenjangan yang dikembangkan oleh Hans Nawiasky. ${ }^{20}$

Peraturan Desa sebagai peraturan lokal dibentuk berdasarkan asas-asas peraturan perundang-undangan. A. Hamid S. Attamimi berpendapat, bahwa asas pembentukan peraturan perundang-undangan yang patut khusus nya dalam ranah keindonesiaan, terdiri atas: Cita Hukum Indonesia, Asas Negara Berdasarkan Hukum, Asas Pemerintahan Berdasarkan Konstitusi dan asas-asas lainnya. Dalam pembentukan peraturan perundang-undangan, disamping menganut asas-asas pembentukan perundang-undangan yang baik, juga berlandasakan juga pada asas-asas hukum umum, yang terdiri atas asas hukum umum negara berdasarkan atas hukum, asas hukum umum pemerintahan berasarkan sistem konstitusi, asas hukum negara berdasarkan kedaulatan rakyat. $^{21}$

${ }^{19}$ Menurut ahli hukum dari austria Hans Kelsen (1881-1973)memperkenalkan teori yang disebut dengan dengan stufentheorie yang dimaksudnya adalah laws as forming a hierarchical strukture atau peraturan-peraturan membentuk susunan bertingkat dimana setiap norma yang lebih rendah menemukan justifikasinya pada norma yang lebih tinggi sampai puncak norma yang dicapai yang disebut dengan norma fundamental atau Grundnorm yang memberikan keabsahan (Validity) dan kesatuan (Unity) atas semua tertib hukum. Ahsin Thohari, Hak Konstitusional Dalam Hukum Tata Negara Indonesia, Erlangga, Jakarta, 2016. HIm. 149

${ }^{20}$ Hans Nawiasky, Salah seorang murid hans kelsen mengembangkan teori gurunya tentang jenjang norma dalam kaitannya dengan suatu negara. Hans Nawiasky dalam bukunya yang berjudul Allgemeine Rechtslehre mengemukakan bahwa sesuai dengan teori Hans Kelsen, maka suatu norma hukum dari negara manapun selalu berlapis-lapis dan berjenjang-jenjang. Norma yang dibawah berlaku, bersumber dan berdasar dari norma yang llebih tinggi, norma yang lebih tinggi berlaku, bersumber dan berdasar pada norma yang lebih tinggi lagi, sampai pada suatu norma tertinggi yang disebut norma dasar. Hans Nawiasky juga berpendapat bahwa selain norma itu berlapislapis dan berjenjang-jenjang, norma hukum dari suatu negara itu juga berkelompokkelompok dan pengelompokkan norma hukum dalam suatu negara iu terdiri atas empat kelompok besar yaitu: Kelompok I : Staatfundamentalnorm, Kelompok II : Staatsgrundgesetz, Kelompok III : Formell Gesetz, Kelompok IV : Verordnung \& Autonome Satzung. Maria Farida Indrati, Ilmu Perundang-undangan, Cet 5, Kanisius, Yogyakarta, 2007. hlm. 44 63.

${ }_{21}$ Jimly Asshidiqie, Perihal Undang-Undang, Rajawali Pers, Jakarta, 2010. hlm. 
Peraturan Desa sebagai perpanjangan dari Peraturan Daerah kab/kota, memiliki asas yang dikemukakan oleh Hamid Attamimi tersebut. Cita hukum yang disebutkan bahwa dengan adanya peraturan desa, diharapkan bisa mengatur masyarakat desa dan membuat masyarakat desa lebih memiliki jaminan hukum, kepastian hukum, menciptakan keadilan yang menimbulkan manfaat bagi masyarakat desa. Asas negara berasarkan hukum yang peraturan desa merupakan suatu ketentuan yang berlaku bagi masyarakat desa tertentu dan memiliki kekuatan mengikat. Asas pemerintahan berdasarkan konstitusi, seperti yang dikemukakan pasal $18 \mathrm{~B}$ ayat (2), dimana masyarakat desa sangat erat sekali dengan adat istiadat.

Jika berangkat dari pendapat Hamid Attamimi diatas, Peraturan Desa memenuhi asas pembentukan peraturan perundang-undangan. Peraturan desa dapat dikategorikan dengan Peraturan Perundangundangan. Dalam pasal 7 ayat (1) Undang-undang nomor 10 Tahun 2004 tentang pembentukan peratuan perundang-undangan, jenis hierarki perundang-undangan adalah sebagai berikut:

1. Undang-Undang Dasar Negara Republik Indonesia Tahun 1945

2. Undang-Undang/Peraturan Pemerintah Pengganti Undang-Undang

3. Peraturan Pemerintah

4. Peraturan Presiden

5. Peraturan Daerah.

Ayat (2) nya menjelaskan bahwa peraturan daerah meliputi:

1. Peraturan daerah provinsi

2. Peraturan daerah kabupaten/kota

3. Peraturan desa

Perbandingan Pasal 7 ayat (1) undang- undang Nomor 10 Tahun 2004 dengan Pasal 7 ayat (1) Undang-undang No. 12 Tahun 2011 tentang Pembentukan Peraturan Perundang-undangan, adalah sebagai berikut. Jenis dan Hierarki peraturan perundang-undangan:

1. Undang-Undang Dasar Negara Republik Indonesia Tahun 1945 
2. Ketetapan Majelis Permusyawaratan Rakyat

3. Undang-Undang/ Perppu

4. Peraturan Pemerintah

5. Peraturan Presiden

6. Peraturan Daerah Provinsi

7. Peratuan Daerah Kabupaten/Kota.

Setelah berlakunya Undang-Undang Nomor 12 Tahun 2011 tentang Pembentukan Peraturan Perundang-Undangan, Peraturan Desa tidak disebutkan secara eksplisit sebagai salah satu peraturan perundangundangan sebagaimana yang diatur dalam Pasal 7 ayat (2) Undangundang Nomor 10 Tahun 2004. Hal ini menimbulkan perdebatan apakah peraturan desa masih termasuk dalam peraturan perundang-undangan atau tidak. Jika ditelaah dalam Pasal 8 ayat (1) Undang-Undang Nomor 12 Tahun 2011 yang berbunyi : "Jenis Peraturan Perundang-undangan selain sebagaimana dimaksud dalam pasal 7 ayat (1) mencakup peraturan yang ditetapkan oleh Majelis Permusyawaratan Rakyat, Dewan Perwakilan Rakyat, Dewan Perwakilan Daerah, Mahkamah Agung, Mahkamah Konstitusi, Badan Pemeriksa Keuangan, Komisi Yudisial, Bank Indonesia, Menteri, badan, lembaga atau komisi yang setingkat yang dibentuk dengan Undang-Undang atau Pemerintah atas perintah UndangUndang, dewan Perwakilan Rakyat Daerah Provinsi, Gubernur, Dewan Perwakilan Rakyat Daerah Kabupaten/Kota, Bupati/ Walikota, Kepala Desa atau yang setingkat".

Jika dianalisa Pasal 8 ayat (1) tidak menyebutkan secara rinci peraturan desa tetapi hanya menyebutkan Peraturan yang ditetapkan kepala desa atau setingkat sedangkan peraturan desa dibuat oleh Badan Permusyawaratan Desa dengan persetujuan bersama kepala desa. Meskipun tidak disebutkan secara rinci jika melihat bunyi pasal 8 ayat (2) "Peraturan Perundang-undangan sebagaimana dimaksud pada ayat (1) diakui keberadaannya dan mempunyai kekuatan hukum mengikat sepanjang diperintahkan oleh Peraturan Perundang-undangan yang 
lebih tinggi atau dibentuk berdasarkan kewenangan". Diakui nya keberadaan peraturan desa dan mempunyai kekuatan hukum yang mengikat yang dipertegas dalam Pasal 8 ayat (2) ini terlihat bahwasanya peraturan desa mendapatkan atribusi kewenangan. Atribusi kewenangan ialah pemberian kewenangan membentuk peraturan perundang-undangan yang diberikan oleh Grondwet (Undang-Undang Dasar) atau wet (UndangUndang) kepada suatu lembaga negara/pemerintahan. ${ }^{22}$ Atribusi $^{2}$ kewenangan ini diperoleh peraturan desa dari Undang-undang nomor 6 tahun 2014 tentang desa sebagaimana diatur dalam Pasal 69 sebagaimana berbunyi:

1. Jenis peraturan di Desa terdiri atas Peraturan Desa, peraturan bersama Kepala Desa, dan peraturan Kepala Desa.

2. Peraturan sebagaimana dimaksud pada ayat (1) dilarang bertentangan dengan kepentingan umum dan/atau ketentuan peraturan perundang-undangan yang lebih tinggi.

3. Peraturan Desa ditetapkan oleh Kepala Desa setelah dibahas dan disepakati bersama Badan Permusyawaratan Desa.

4. Rancangan Peraturan Desa tentang Anggaran Pendapatan dan Belanja Desa, pungutan, tata ruang, dan organisasi Pemerintah Desa harus mendapatkan evaluasi dari Bupati/Walikota sebelum ditetapkan menjadi Peraturan Desa.

5. Hasil evaluasi sebagaimana dimaksud pada ayat (4) diserahkan oleh Bupati/Walikota paling lama 20 (dua puluh) hari kerja terhitung sejak diterimanya rancangan peraturan tersebut oleh Bupati/Walikota

6. Dalam hal Bupati/Walikota telah memberikan hasil evaluasi sebagaimana dimaksud pada ayat (5), Kepala Desa wajib memperbaikinya.

7. Kepala Desa diberi waktu paling lama 20 (dua puluh) hari sejak diterimanya hasil evaluasi untuk melakukan koreksi.

${ }^{22}$ Maria Farida Indrati, IImu Perundang-undangan.. Op.Cit. hlm. 55 
8. Dalam hal Bupati/Walikota tidak memberikan hasil evaluasi dalam batas waktu sebagaimana dimaksud pada ayat (5), Peraturan Desa tersebut berlaku dengan sendirinya.

9. Rancangan Peraturan Desa wajib dikonsultasikan kepada masyarakat Desa.

10. Masyarakat Desa berhak memberikan masukan terhadap Rancangan Peraturan Desa.

11.Peraturan Desa dan peraturan Kepala Desa diundangkan dalam Lembaran Desa dan Berita Desa oleh sekretaris Desa.

12. Dalam pelaksanaan Peraturan Desa sebagaimana dimaksud pada ayat (1), Kepala Desa menetapkan Peraturan Kepala Desa sebagai aturan pelaksanaannya.

Kemudian dalam Pasal 101 Undang-Undang Nomor 12 Tahun 2011 yang berbunyi: "semua Peraturan Perundang-undangan yang merupakan peraturan pelaksanaan dari Undang-Undang Nomor 10 Tahun 2004, dinyatakan masih tetap berlaku sepanjang tidak bertentangan dengan ketentuan dalam Undang-Undang ini”. Dengan demikian status hukum peraturan desa sangat jelas mendapatkan atribusi kewenangan dari undang-undang nomor 6 tahun 2014 tentang desa.

\section{Kesimpulan dan saran}

\section{Kesimpulan}

Peraturan desa dalam Undang-undang nomor 10 tahun 2004 tentang pembentukan peraturan perundang-undangan merupakan salah satu peraturan dalam hierarki perundang-undangan yang diatur dalam pasal 7 ayat (2). Namun, setelah keluarnya undang-undang nomor 12 tahun 2011 peraturan desa tidak disebutkan secara eksplisit termasuk dalam hierarki perundang-undangan sebagaimana diatur diatur dalam pasal 7 ayat (1). Meskipun tidak disebutkan secara rinci jika melihat bunyi pasal 8 ayat (2) "Peraturan Perundang-undangan sebagaimana dimaksud pada ayat (1) diakui keberadaannya dan mempunyai kekuatan hukum 
mengikat sepanjang diperintahkan oleh Peraturan Perundangundangan yang lebih tinggi atau dibentuk berdasarkan kewenangan. Diakui nya keberadaan peraturan desa dan mempunyai kekuatan hukum yang mengikat yang dipertegas dalam Pasal 8 ayat (2) ini terlihat bahwasanya peraturan desa mendapatkan atribusi kewenangan dari undang-undang nomor 6 tahun 2014 tentang Desa. Peraturan desa merupakan regulasi yang sangat penting, apalagi di Indonesia. Hal tersebut dikarenakan Indonesia merupakan Negara yang multi, yang menimbulkan keberagaman sumber daya alam, sumber daya manusia, kebutuhan masyarakat yang berbeda-beda, luas wilayah, adat istiadat, Agama dan budaya. Yang tidak cukup hanya di atur oleh undang-undang dan peraturan daerah, yang materi muatannya memiliki cakupan yang lebih luas.

\section{Saran}

Setiap Desa harus memiliki peraturan desa untuk mengatur dan mengurus rumah tangganya sendiri sehingga kewenangan yang dimilikinya berjalan efektif. Dengan begitu Dinas Pemberdayaan Masyarakat Dan Desa (DPMD) harus melakukan peninjauan ke setiap desa-desa untuk memberikan penyuluhan prosedur dan mekanisme membuat peraturan desa serta memaparkan pentingnya peraturan desa dalam mengimplementasi kebijakan pemerintah desa terutama terkait dengan pembangunan baik infrastruktur maupun suprastruktur di desa. 


\section{DAFTAR PUSTAKA}

\section{Buku-buku}

Ahsin Thohari, Hak Konstitusional Dalam Hukum Tata Negara Indonesia, Erlangga, Jakarta, 2016

Azmi Fendri, Pengaturan Kewenangan Pemerintah Dan Pemerintah Daerah Dalam Pemanfaatan Sumber Daya Mineral Dan

Batu Bara, PT Raja Grafindo Persada, Jakarta, 2016

Ellydar Chaidir, Sistem Pemerintahan Negara Republik Indonesia, Total Media, Yogyakarta, 2008

Haw Widjaja, Otonomi Daerah Dan Daerah Otonom, PT Raja Grafindo Persada, Jakarta, 2016

Jimly Asshidiqie, Perihal Undang-Undang, Rajawali Pers, Jakarta, 2010

J. Kaloh, Mencari Bentuk Daerah, Rineka Cipta, Jakarta, 2007

Josef Riwu Kaho, Prospek Otonomi Daerah di Negara Republik Indonesia, PT. Raja Grafindo Persada, Jakarta, 2002.

Mahfud MD, Konstitusi Dan Hukum Dalam Kontroversi Isu, Jakarta, PT Raja Grafindo. Persada, 2009.

Maria Farida Indrati, IImu Perundang-undangan, Cet 5, Kanisius, Yogyakarta, 2007

Mudrajat Kuncoro, Otonomi Daerah Menuju Era Baru Pembangunan Daerah, Edisi, Erlangga, Jakarta, 2014

Muhadam Labolo, Memahami Ilmu Pemerintahan, PT Raja Grafindo Persada, Jakarta, 2006

Rahyunir Rauf, Sri Maulidiah, Badan Permusyawaratan Desa, Zanafa, Pekanbaru, 2016

Rozali Abdullah, Pelaksanaan Otonomi Luas Dengan Pemilihan Kepala Daerah Secara Langsung, PT Raja Grafindo Persada, Jakarta, 2011

Siswanto Sunarno, Hukum Pemerintahan Daerah di Indonesia, Sinar Grafika, Jakarta, 2006

Suratman, Metode Penelitian Hukum, Alfabeta, Bandung, 2014

Yuliandri, Asas-Asas Pembentukan Peraturan Perundang-undangan yang baik, Rajawali Pers, Jakarta, 2010

Zainuddin Ali, Metode Penelitian Hukum, Sinar Grafika, Jakarta, 2014.

Peraturan Perundang-undangan

Undang-Undang Dasar Negara Republik Indonesia Tahun 1945

Undang-Undang Nomor 12 Tahun 2011 Tentang Pembentukan Peraturan Perundang-Undangan.

Undang-Undang Nomor 6 Tahun 2014 Tentang Desa

Undang-undang Nomor 23 Tahun 2014 Tentang Pemerintahan Daerah

Internet

http://carapedia.com/peraturan_desa_info661.html

www.hukumonline.com 